Article

\title{
Alkylation of toluene with tert-butyl alcohol over HPW-modified Hß zeolite
}

\author{
Yuanyuan Wang a, Hua Song a,*, Xinglong Sun ${ }^{\mathrm{b}}$ \\ a Northeastern Petroleum University, Chemistry and Chemical Engineering, Daqing 163318, Heilongjiang, China \\ b Daqing Petrochemical Engineering Co., Ltd., Daqing 163714, Heilongjiang, China
}

A R T I C L E I N F

Article history:

Received 29 September 2016

Accepted 27 October 2016

Published 5 December 2016

\section{Keywords:}

Alkylation

Toluene

tert-Butyl alcohol

$\mathrm{H}_{3} \mathrm{PW}_{12} \mathrm{O}_{40}$

B acidity

$\mathrm{H} \beta$ zeolite

\begin{abstract}
A B S T R A C T
An $\mathrm{H} \beta$-supported heteropoly acid $\left(\mathrm{H}_{3} \mathrm{PW}_{12} \mathrm{O}_{40}(\mathrm{HPW}) / \mathrm{H} \beta\right)$ catalyst was successfully prepared by wetness impregnation, and investigated in the alkylation of toluene with tert-butyl alcohol for the synthesis of 4-tert-butyltoluene (PTBT). X-ray diffraction, scanning electron microscopy, transmission electron microscopy, fourier-transform infrared spectroscopy, inductively coupled plasma-optical emission spectrometry, the brunauer emmett teller (BET) method, temperature-programmed $\mathrm{NH}_{3}$ desorption, and pyridine adsorption infrared spectroscopy were used to characterize the catalyst. The results showed that loading HPW on $\mathrm{H} \beta$ effectively increased the B acidity and decreased the pore size of $\mathrm{H} \beta$. The B acidity of $\mathrm{HPW} / \mathrm{H} \beta$ was $142.97 \mu \mathrm{mol} / \mathrm{g}$, which is $69.74 \%$ higher than that of $\mathrm{H} \beta(84.23 \mu \mathrm{mol} / \mathrm{g})$. The catalytic activity of the HPW/H $\beta$ catalyst was much better than that of the parent $\mathrm{H} \beta$ zeolite because of its high $\mathrm{B}$ acidity. The toluene conversion over $\mathrm{HPW} / \mathrm{H} \beta$ reached $73.1 \%$, which is much higher than that achieved with $\mathrm{H} \beta(54.0 \%)$. When HPW was loaded on $\mathrm{H} \beta$, the BET surface area of $\mathrm{H} \beta$ decreased from 492.5 to $379.6 \mathrm{~m}^{2} / \mathrm{g}$, accompanied by a significant decrease in the pore size from 3.90 to $3.17 \mathrm{~nm}$. Shape selectivity can therefore play an important role and increase the product selectivity of the HPW/H $\beta$ catalyst compared with that of the parent $\mathrm{H} \beta$. PTBT (kinetic diameter $0.58 \mathrm{~nm}$ ) can easily diffuse through the narrowed pores of $\mathrm{HPW} / \mathrm{H} \beta$, but 3-tert-butyltoluene (kinetic diameter $0.65 \mathrm{~nm}$ ) diffusion is restricted because of steric hindrance in these narrow pores. This results in high PTBT selectivity over HPW/H $\beta$ (around 81\%). The $\mathrm{HPW} / \mathrm{H} \beta$ catalyst gave a stable catalytic performance in reusability tests.
\end{abstract}

(C) 2016, Dalian Institute of Chemical Physics, Chinese Academy of Sciences. Published by Elsevier B.V. All rights reserved.

\section{Introduction}

4-tert-Butyltoluene (PTBT) is commercially important because its derivatives, such as 4-tert-butylbenzoic acid and 4-tert-butylbenzaldehyde, are used in the fine chemical and petrochemical industries [1-3]. Conventionally, toluene butylation reactions are conducted over catalysts such as $\mathrm{AlCl}_{3}$, sulfuric and phosphoric acids, and boron trifluoride. However, these acid catalysts are not environmentally benign or reusable and corrode equipment. Considerable attention has therefore been devoted to development of environmentally friendly solid acid catalysts $[4,5]$.

Zeolites are regarded as a good choice because of their unique pore structures and acidic properties. Zeolites have been investigated for toluene alkylation with tert-butyl alcohol (TBA) [4,6-10]. Zeolite $\beta$, which has a three-dimensional interconnecting pore system and high acidity, shows high catalytic activity. Pai et al. [4] reported that the catalytic activities of $\mathrm{H} \beta$ $(\mathrm{Si} / \mathrm{Al}=25)$ and $\mathrm{HY}(\mathrm{Si} / \mathrm{Al}=30)$ were better than that of HMCM-22 $(\mathrm{Si} / \mathrm{Al}=52)$ in vapor-phase butylation of toluene.

* Corresponding author. Tel: +86-459-6503167; Fax: +86-459-6506498; E-mail: songhua2004@sina.com DOI: 10.1016/S1872-2067(16)62587-1 | http://www.sciencedirect.com/science/journal/18722067 | Chin. J. Catal., Vol. 37, No. 12, December 2016 
Mravec et al. [9] reported that the most active zeolite catalysts for liquid-phase butylation of toluene were $\mathrm{H} \beta(\mathrm{Si} / \mathrm{Al}=12.5)$ and $\mathrm{HM}(\mathrm{Si} / \mathrm{Al}=17.5)$. In our previous study [11], we found that $\mathrm{H} \beta$ showed high catalytic activity in toluene alkylation with TBA. However, the para selectivity, i.e., for PTBT, was $69.6 \%$ and the meta selectivity, i.e., for 3-tert-butyltoluene (MTBT), was $26.9 \%$ over $\mathrm{H} \beta$. The selectivity for the desired product, i.e., PTBT, was therefore low. The dimensions of the 12-ring portals of the parent $\mathrm{H} \beta$ are $0.67 \mathrm{~nm} \times 0.66 \mathrm{~nm}$ [12], and the kinetic diameters of PTBT and MTBT are 0.58 and $0.65 \mathrm{~nm}$ [9], respectively. The shape selectivity has little effect on the PTBT selectivity over $\mathrm{H} \beta$. However, the shape selectivity can be greatly improved by slightly narrowing the 12-ring portals of the parent $\mathrm{H} \beta$. Modification with a metal oxide is a highly efficient method for improving the para selectivity by reducing the number of external acid sites and adjusting the pore entrance size. Kostrab et al. [5] reported that cerium-modified HM maintained a constant high PTBT selectivity (near 90\%) but decreased the catalytic activity, i.e., improving the para selectivity by metal oxide modification usually decreases the catalytic activity. New and efficient catalysts for PTBT synthesis by toluene alkylation with TBA that enhance the para selectivity but also maintain or increase the catalytic activity are therefore needed.

Zeolite-catalyzed toluene alkylation with alcohols is generally considered to proceed via carbonium ion mechanisms [13] and the active sites are $\mathrm{B}$ acid sites [6-14]. Because of its strong $\mathrm{B}$ acidity, $\mathrm{H}_{3} \mathrm{PW}_{12} \mathrm{O}_{40}$ (HPW) is a promising catalyst, with high activity in toluene alkylation with alcohols. The specific surface area of HPW is low (close to $5 \mathrm{~m}^{2} / \mathrm{g}$ ), therefore many attempts have been made to support HPW using various acidic or neutral solid materials [15-19]. Zeolite $\beta$ is a promising support for acid-catalyzed alkylation reactions because of its high specific surface area, high thermal stability, and hardness.

HPW loading is expected to improve the para selectivity because HPW loading narrows the pores and improves the shape selectivity. HPW loading is also expected to increase the catalytic activity because of the increased number of $\mathrm{B}$ acid sites. To the best of our knowledge, there are no reports of toluene alkylation with TBA catalyzed by $\mathrm{H} \beta$-supported HPW. It is therefore of interest to investigate the catalytic activities of HPW-modified H $\beta$ catalysts for toluene alkylation with TBA.

The aim of the present study was to evaluate the catalytic behavior of $\mathrm{HPW} / \mathrm{H} \beta$ in toluene alkylation with TBA under liquid reaction conditions. $\mathrm{HPW} / \mathrm{H} \beta$ was obtained using a wetness impregnation method and fully characterized using X-ray diffraction (XRD), scanning electron microscopy (SEM), transmission electron microscopy (TEM), fourier transform infrared spectroscopy (FT-IR), inductively coupled plasma-optical emission spectrometry (ICP-OES), the brunauer emmett teller (BET) method, temperature-programmed $\mathrm{NH}_{3}$ desorption ( $\mathrm{NH}_{3}-\mathrm{TPD}$ ), and pyridine adsorption FT-IR (Py-IR) spectroscopy. Our objective was to correlate the channel structures and acidity of the $\mathrm{HPW} / \mathrm{H} \beta$ catalyst with its catalytic properties in toluene alkylation.

\section{Experimental}

\subsection{Catalyst preparation}

The starting material was $\mathrm{Na} \beta$ zeolite (Zeolyst International). $\mathrm{H} \beta$ powder was prepared by impregnation of $\mathrm{Na} \beta$ with $\mathrm{NH}_{4} \mathrm{NO}_{3}$ (Sigma Aldrich, reagent grade) aqueous solution using a reported procedure [20]. After impregnation, the zeolite was filtered, dried at $120^{\circ} \mathrm{C}$ for $12 \mathrm{~h}$, and calcined at $450{ }^{\circ} \mathrm{C}$ for $4 \mathrm{~h}$ to give $\mathrm{H} \beta$. $\mathrm{H}_{3} \mathrm{PW}_{12} \mathrm{O}_{40} \cdot x \mathrm{H}_{2} \mathrm{O}$ (HPW, Sigma-Aldrich, reagent grade) was dried at $200{ }^{\circ} \mathrm{C}$ in a furnace for $24 \mathrm{~h}$ to remove water. HPW-modified $\mathrm{H} \beta$ was prepared by wetness impregnation with an ethanol solution of the desired amount of HPW. The product was aged at ambient temperature for $8 \mathrm{~h}$, dried at 60 ${ }^{\circ} \mathrm{C}$ overnight, and calcined at $450{ }^{\circ} \mathrm{C}$ for $4 \mathrm{~h}$. The prepared catalyst is denoted by $\mathrm{HPW} / \mathrm{H} \beta$.

\subsection{Catalyst characterization}

XRD analysis was performed using a D/max-2200PC X-ray diffractometer with $\mathrm{Cu} K_{\alpha}$ radiation at $40 \mathrm{kV}$ and $30 \mathrm{~mA}$, in the scanning range $2 \theta=10^{\circ}-80^{\circ}$ at a scanning rate of $4^{\circ} / \mathrm{min}$.

The catalyst surface morphology was examined using SEM (Zeiss-SIGMA).

TEM examinations were performed using a JEM-1010 instrument (JEOL). Samples were dispersed in ethanol and placed on a carbon grid before TEM examinations.

IR spectra were recorded using a Bruker FT-IR spectrometer (Tensor 27) in the wavenumber range $4000-400 \mathrm{~cm}^{-1}$ at a 4 $\mathrm{cm}^{-1}$ resolution. $\mathrm{KBr}$ pellets containing $5 \%$ of powder sample were used.

The HPW content of the catalyst was determined using ICP-OES (Perkin Elmer Optima 2000DV instrument).

The physicochemical properties of the supports and catalysts were investigated by the BET method using a NOVA2000e instrument (Micromeritics). All the samples were outgassed at $200{ }^{\circ} \mathrm{C}$ until the vacuum pressure was $6 \mathrm{~mm} \mathrm{Hg}$. $\mathrm{N}_{2}$ adsorption isotherms were recorded at $-196^{\circ} \mathrm{C}$.

The catalyst acidity was measured using $\mathrm{NH}_{3}-\mathrm{TPD}$ (Quantachrome Chembet-3000 characterization system). A sample (200 mg) was pretreated at $550{ }^{\circ} \mathrm{C}$ for $1 \mathrm{~h}$ in dry $\mathrm{He}(50$ $\mathrm{mL} / \mathrm{min}$ ) and cooled to $120{ }^{\circ} \mathrm{C}$. It was then exposed to $10 \%$ $\mathrm{NH}_{3} / 90 \%$ He for $1 \mathrm{~h}$. After purging the catalyst with He for $1 \mathrm{~h}$, a TPD plot was obtained at a heating rate of $10{ }^{\circ} \mathrm{C} / \mathrm{min}$ from 120 to $600{ }^{\circ} \mathrm{C}$.

The Py-IR spectra were recorded using a Bruker FT-IR spectrometer (Tensor 27) and a high-temperature vacuum cell. The sample powder was pressed into a self-supporting wafer, and the spectra were recorded in the wavenumber range $4000-400 \mathrm{~cm}^{-1}$ at a $4 \mathrm{~cm}^{-1}$ resolution. Before each experiment, the sample was pressed into thin pellets $(10-30 \mathrm{mg})$ of diameter $16 \mathrm{~mm}$ and activated in situ under vacuum $\left(10^{-5} \mathrm{~Pa}\right)$ at 170 ${ }^{\circ} \mathrm{C}$ overnight. Excess pyridine was introduced at $150{ }^{\circ} \mathrm{C}$ after activation. The concentrations of $\mathrm{B}$ sites and $\mathrm{L}$ sites were determined from the integrated area bands of $\mathrm{PyH}^{+}$(around 1540 $\mathrm{cm}^{-1}$ ) and PyL (around $1450 \mathrm{~cm}^{-1}$ ) species using the molar extinction coefficients of the bands.

\subsection{Catalytic tests}


Table 1

Catalytic results for toluene alkylation with TBA over various catalysts.

\begin{tabular}{|c|c|c|c|c|c|}
\hline \multirow{2}{*}{ Catalyst } & \multirow{2}{*}{ Toluene conversion $(\%)$} & \multicolumn{3}{|c|}{ Distribution of products (\%) } & \multirow{2}{*}{ PTBT selectivity (\%) } \\
\hline & & PTBT & MTBT & others & \\
\hline$\overline{\mathrm{H} \beta}$ & 54.0 & 37.6 & 14.5 & 1.9 & 69.6 \\
\hline HM & 32.7 & 26.0 & 6.1 & 0.6 & 79.5 \\
\hline HY & 40.7 & 28.9 & 11.0 & 0.8 & 71.0 \\
\hline HZSM-5 & 4.5 & 3.2 & 1.1 & 0.2 & 71.1 \\
\hline $\mathrm{HPW} / \mathrm{H} \beta$ & 73.1 & 59.1 & 13.5 & 0.5 & 80.8 \\
\hline $\mathrm{HPMo} / \mathrm{H} \beta$ & 66.3 & 53.6 & 12.4 & 0.3 & 80.8 \\
\hline
\end{tabular}

Reaction conditions: TBA/toluene molar ratio $=3 / 1$, catalyst amount $=1.0 \mathrm{~g}$, reaction temperature $=180{ }^{\circ} \mathrm{C}$, reaction time $=4 \mathrm{~h}$.

Side-chain alkylation of toluene with TBA was performed in a laboratory autoclave reactor $(300 \mathrm{~mL})$ at $180{ }^{\circ} \mathrm{C}$. In a typical experiment, toluene (10 mL, $94 \mathrm{mmol}$; 98\%, Aladdin) and TBA (28 mL, $283 \mathrm{mmol}$; 98\%, Aladdin) were mixed with cyclohexane (60 mL, 99\%, Aladdin) as a solvent. Then the zeolite catalyst (1.0 g) was added. The reaction system was sealed and purged continuously with $\mathrm{N}_{2}$ for $30 \mathrm{~min}$. The mixture was heated to a certain temperature to start the alkylation reaction. After the reaction, the mixture was cooled to room temperature, and the zeolite catalyst was removed by filtration. The liquid phase was analyzed using a GC-14C gas chromatograph equipped with an SE-30 capillary column $(\phi 0.25 \mathrm{~mm} \times 50 \mathrm{~m})$. The analysis was performed at an initial temperature of $60{ }^{\circ} \mathrm{C}$ for $2 \mathrm{~min}$, a ramping rate of $10^{\circ} \mathrm{C} / \mathrm{min}$, and a final temperature of $220^{\circ} \mathrm{C}$, which was held for $10 \mathrm{~min}$, with $\mathrm{N}_{2}$ as the carrier gas. A number of runs were performed to check the reproducibility of the experimental results; it was found to be excellent. Typical errors were in the range $\pm 2 \%$.

\section{Results and discussion}

\subsection{Catalyst selection and characterization}

Toluene is not active enough to undergo Friedel-Crafts alkylation in the absence of a catalyst. The selection of a suitable catalyst is therefore crucial for highly efficient alkylation of toluene with TBA. Initially, unmodified zeolites, i.e., H $\beta, \mathrm{HM}, \mathrm{HY}$, and HZSM-5, were used as catalysts for toluene butylation. The results are listed in Table 1. Two monoalkylated products were detected, namely a large amount of PTBT (the para isomer) and MTBT (the meta isomer). However, no 2-tert-butyltoluene (OTBT, the ortho isomer) was detected. PTBT is the major product because steric hindrance of the methyl group and the large tert-butyl group favor formation of the para isomer. It is also favored by shape selectivity because of the regular channel structures of zeolite catalysts. The formation of OTBT is hindered by the methyl group ortho to the tert-butyl group. A trace amount of the dialkylated product, 3,5-di-tert-butyltoluene, formed by further alkylation of the monoalkylated products PTBT and MTBT, was also detected. This can also be explained by the steric effects of all the alkyl groups being in meta positions.

It is clear that the $\mathrm{H} \beta$ zeolite was the most effective catalyst (Table 1), this can be ascribed to the special structure of the $H \beta$ zeolite and its higher acidity [11]. The toluene conversion was
$54.0 \%$ and the selectivity for PTBT was just $69.6 \%$ over $\mathrm{H} \beta$ zeolite, i.e., lower selectivity for the desired product, PTBT. Based on the potential benefits of heteropoly acid modification, heteropoly-acid-modified $\mathrm{H} \beta$ zeolites were then investigated in this reaction (Table 1). As expected, the catalytic performances of these modified $\mathrm{H} \beta$ zeolites were better than that of $\mathrm{H} \beta$ zeolite, especially in the case of $\mathrm{HPW} / \mathrm{H} \beta$. The toluene conversion and selectivity for PTBT over HPW/H $\beta$ were $73.1 \%$ and $80.8 \%$ respectively, which are both better than the results obtained using $\mathrm{H} \beta$ zeolite. HPW/H $\beta$ therefore had the highest activity and was chosen as the catalyst for further investigation.

The XRD patterns of the $\mathrm{H} \beta$ and $\mathrm{HPW} / \mathrm{H} \beta$ samples are shown in Fig. 1. The main diffraction peak from the $\mathrm{H} \beta$ zeolite was observed at $2 \theta=22.5^{\circ}$. No additional diffraction peaks were observed in the XRD pattern of $\mathrm{HPW} / \mathrm{H} \beta$, indicating that HPW was well dispersed on the H $\beta$ zeolite surface and no obvious structural changes were caused by HPW loading. However, a slight decrease in the diffraction peak intensity was observed after HPW loading. This indicates that some loss of crystallinity occurred after HPW loading by impregnation and heat treatment. These processes would also cause collapse of the $\mathrm{H} \beta$ framework, which is another reason for the decreased intensity.

The SEM images of the $\mathrm{H} \beta$ and HPW/H $\beta$ samples in Fig. 2 show that the outer surface of $\mathrm{HPW} / \mathrm{H} \beta$ was essentially unchanged compared with that of the $\mathrm{H} \beta$ zeolite. The HPW/H $\beta$ crystal size was around $200-300 \mathrm{~nm}$.

The morphologies of the $\mathrm{H} \beta$ and $\mathrm{HPW} / \mathrm{H} \beta$ samples were

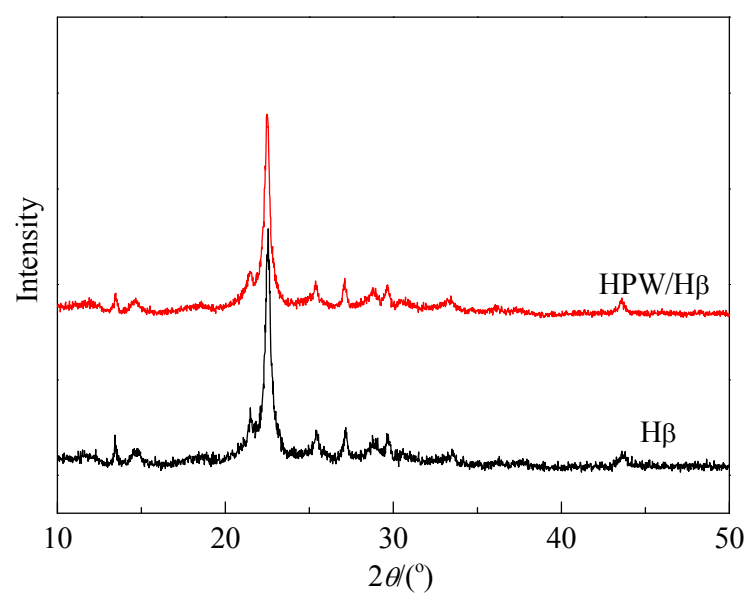

Fig. 1. XRD patterns of parent $H \beta$ and $H P W / H \beta$ catalyst. 

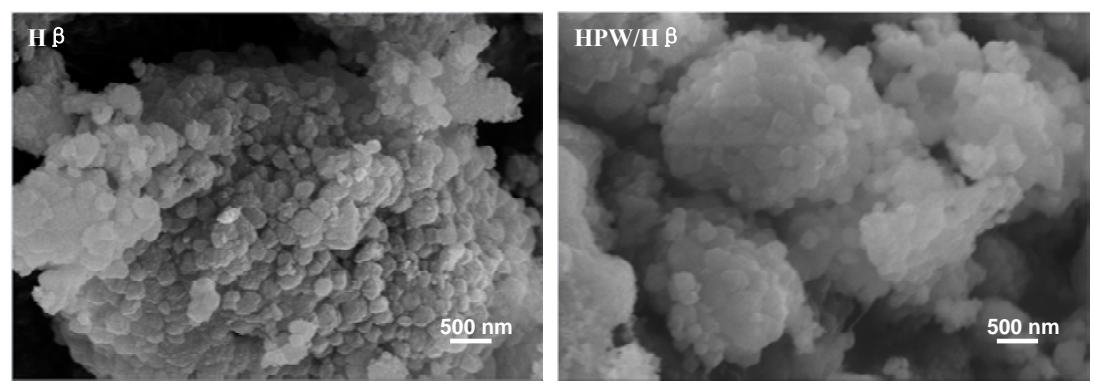

Fig. 2. SEM images of $H \beta$ and $H P W / H \beta$
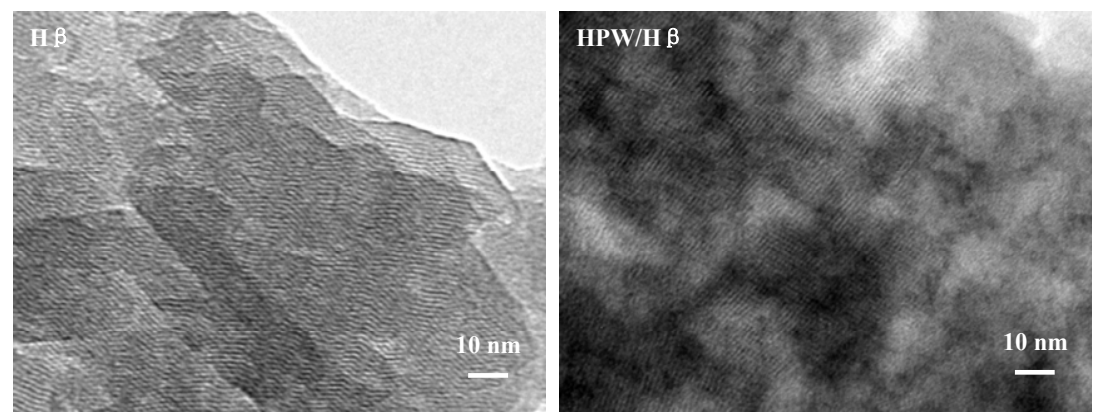

Fig. 3. TEM images of $H \beta$ and $H P W / H \beta$.

consistent in the TEM results (Fig. 3). TEM showed that the $\mathrm{H} \beta$ zeolite had a honeycomb structure. In the HPW/H $\beta$ catalyst, HPW was uniformly dispersed on $\mathrm{H} \beta$, and can be distinguished as dark dots in the TEM images.

Fig. 4 shows the FT-IR spectra of HPW, HPW/H $\beta$, and the parent $\mathrm{H} \beta$. In the HPW spectrum, the band at $1082 \mathrm{~cm}^{-1}$ can be assigned to $\mathrm{P}-0$, the broad band at $983 \mathrm{~cm}^{-1}$ can be assigned to $\mathrm{W}=0$, the band at $896 \mathrm{~cm}^{-1}$ can be assigned to $\mathrm{O}-\mathrm{W}-0$ (corner-sharing oxygen), and the very broad band at $809 \mathrm{~cm}^{-1}$ can be assigned to $\mathrm{W}-\mathrm{O}-\mathrm{W}$ (edge-sharing oxygen) [21-22]. The spectrum of $\mathrm{HPW} / \mathrm{H} \beta$ showed a large band at $809 \mathrm{~cm}^{-1}$ and a broad band at $1082 \mathrm{~cm}^{-1}$, attributed to overlapping of the bands from HPW and the $\mathrm{H} \beta$ zeolite at the corresponding positions. In addition, small bands at 983 and $896 \mathrm{~cm}^{-1}$ can be observed in the HPW/H $\beta$ spectrum. These results confirm that HPW was successfully supported on the $\mathrm{H} \beta$ zeolite and there were strong bonding interactions between HPW and $\mathrm{H} \beta$ [23].

The loaded amount of HPW in HPW/H $\beta$, determined using ICP-OES, was $29.6 \%$, which is consistent with the theoretical amount $(30.0 \%)$ (Table 2). The textural properties of the parent $\mathrm{H} \beta$ and $\mathrm{HPW} / \mathrm{H} \beta$ are also listed in Table 2. HPW loading decreased the BET surface area of $\mathrm{H} \beta$ from 492.5 to 379.6 $\mathrm{m}^{2} / \mathrm{g}$, the pore volume decreased from 0.48 to $0.29 \mathrm{~cm}^{3} / \mathrm{g}$, and the pore size decreased from 3.90 to $3.17 \mathrm{~nm}$. These effects are attributed to the HPW entering the $\mathrm{H} \beta$ pores during the modification process [24]. The decrease in the pore size after HPW loading improves the para selectivity. Similar observations were made by Kumar et al. [25]. The dimensions of the 12-ring portals of the parent $\mathrm{H} \beta$ are $0.67 \mathrm{~nm} \times 0.66 \mathrm{~nm}$ [12], and the kinetic diameters of PTBT and MTBT are 0.58 and $0.65 \mathrm{~nm}$, respectively [9]. Shape selectivity therefore has little effect on PTBT selectivity over the $\mathrm{H} \beta$ zeolite; the PTBT selectivity over the parent $\mathrm{H} \beta$ was $69.6 \%$, which is low. However, HPW loading narrows the pore entrances, as confirmed by the decrease in the average pore size from 3.90 to $3.17 \mathrm{~nm}$ (Table 2). Shape selectivity could therefore play a more important role in the product selectivity over the $\mathrm{HPW} / \mathrm{H} \beta$ catalyst than in the case

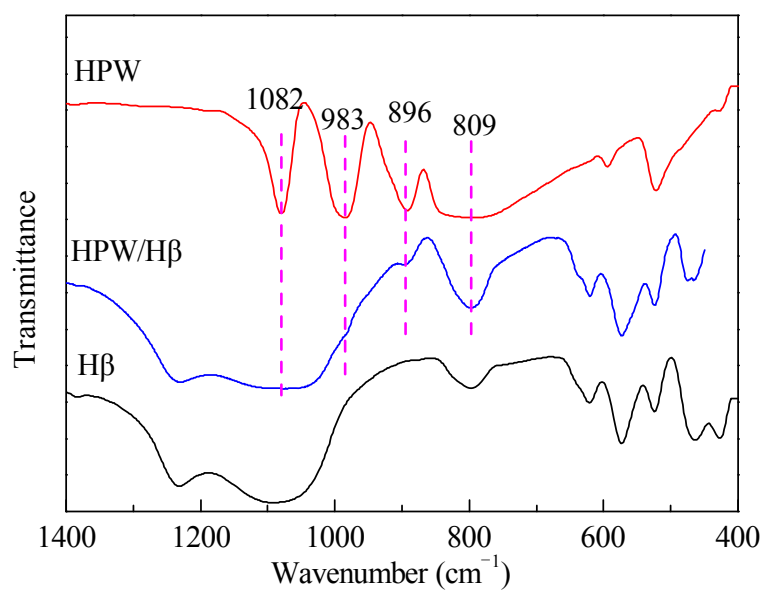

Fig. 4. FT-IR spectra of $H P W, H P W / H \beta$, and $H \beta$.

Table 2

Physicochemical and acidic properties of parent $\mathrm{H} \beta$ and $\mathrm{HPW} / \mathrm{H} \beta$.

\begin{tabular}{lcccccccc}
\hline Sample & $\begin{array}{c}\text { Content of HPW } \\
(\%)\end{array}$ & $\begin{array}{c}\text { Specific surface area } \\
\left(\mathrm{m}^{2} / \mathrm{g}\right)\end{array}$ & $\begin{array}{c}\text { Pore volume } \\
\left(\mathrm{cm}^{3} / \mathrm{g}\right)\end{array}$ & $\begin{array}{c}\text { Pore size } \\
(\mathrm{nm})\end{array}$ & $\begin{array}{c}\text { B acidity } \\
(\mu \mathrm{mol} / \mathrm{g})\end{array}$ & $\begin{array}{c}\text { Lacidity } \\
(\mu \mathrm{mol} / \mathrm{g})\end{array}$ & $\begin{array}{c}\text { Total acidity } \\
(\mu \mathrm{mol} / \mathrm{g})\end{array}$ & $\begin{array}{c}\text { B/L } \\
\text { ratio }\end{array}$ \\
\hline $\mathrm{H} \beta$ & - & 492.5 & 0.48 & 3.90 & 84.23 & 47.17 & 131.40 & 1.79 \\
$\mathrm{HPW} / \mathrm{H} \beta$ & 29.6 & 379.6 & 0.29 & 3.17 & 142.97 & 34.55 & 177.52 & 4.14 \\
\hline
\end{tabular}




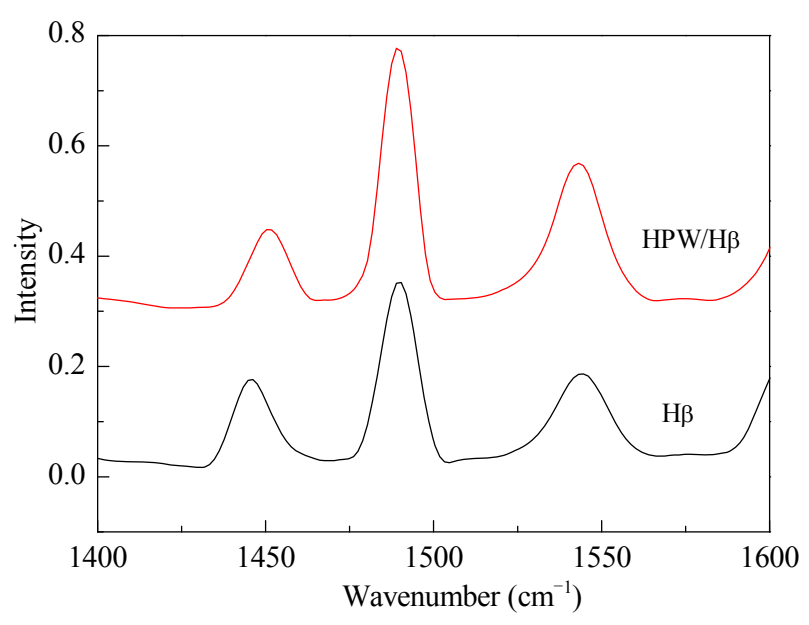

Fig. 5. Py-IR spectra of $H \beta$ and $H P W / H \beta$.

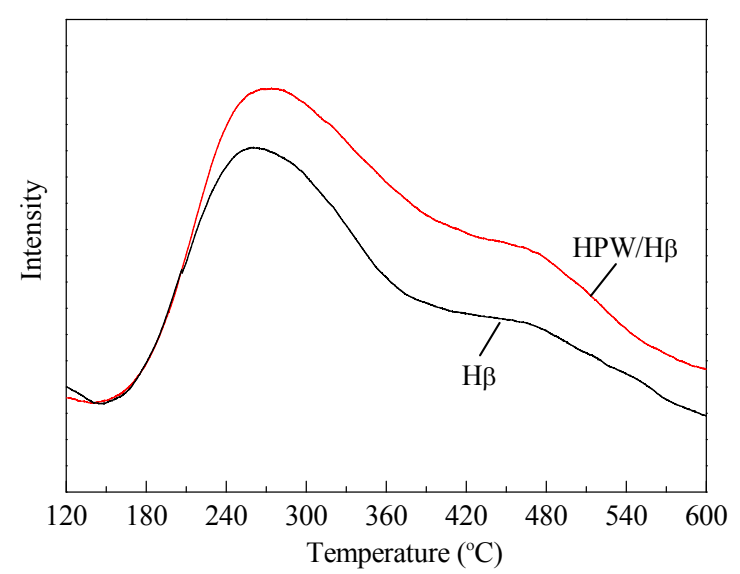

Fig. 6. $\mathrm{NH}_{3}-\mathrm{TPD}$ curves of parent $\mathrm{H} \beta$ and $\mathrm{HPW} / \mathrm{H} \beta$.

of the parent H $\beta$. PTBT can easily diffuse from the narrow pores of $\mathrm{HPW} / \mathrm{H} \beta$, but MTBT diffusion is restricted because of steric hindrance in the narrow pores of $\mathrm{HPW} / \mathrm{H} \beta$. The PTBT selectivity over HPW/H $\beta$ (around 81.0\%) was therefore higher than that over $\mathrm{H} \beta(69.6 \%)$.

The FT-IR spectra of pyridine after desorption at $150{ }^{\circ} \mathrm{C}$ are shown in Table 2 and Fig. 5. The strong absorption peak at $1450 \mathrm{~cm}^{-1}$ is attributed to $\mathrm{L}$ acid sites, and the peak at 1540 $\mathrm{cm}^{-1}$ is attributed to $\mathrm{B}$ acid sites [26-27]. A stronger absorption peak, from $B$ and $L$ acid sites, was observed at $1490 \mathrm{~cm}^{-1}$ [28]. It is clear that the number of $\mathrm{L}$ acid sites in $\mathrm{HPW} / \mathrm{H} \beta$ decreased, whereas the number of $B$ acid sites significantly increased, after HPW loading (see Table 2), leading to an increase in the total number of acid sites and the $\mathrm{B} / \mathrm{L}$ ratio. This is possibly because HPW loading covers some of the acid sties on the $\mathrm{H} \beta$ zeolite. However, new B acid sites are introduced by HPW loading, and this compensates for coverage of the original B acid sites in the parent H $\beta$ by HPW [27]. A significant decrease in the number of $L$ acid sites was observed because of coverage of $L$ acid sites by HPW loading. Zeolite-catalyzed alkylation of toluene with alcohols is generally considered to proceed via carbonium ion mechanisms [13] and the active sites are B acid sites [6,14]. The data in Table 2 show that the B acidity of HPW/H $\beta$ was 142.97 $\mu \mathrm{mol} / \mathrm{g}$, which is $69.74 \%$ higher than that of $\mathrm{H} \beta \quad 84.23$

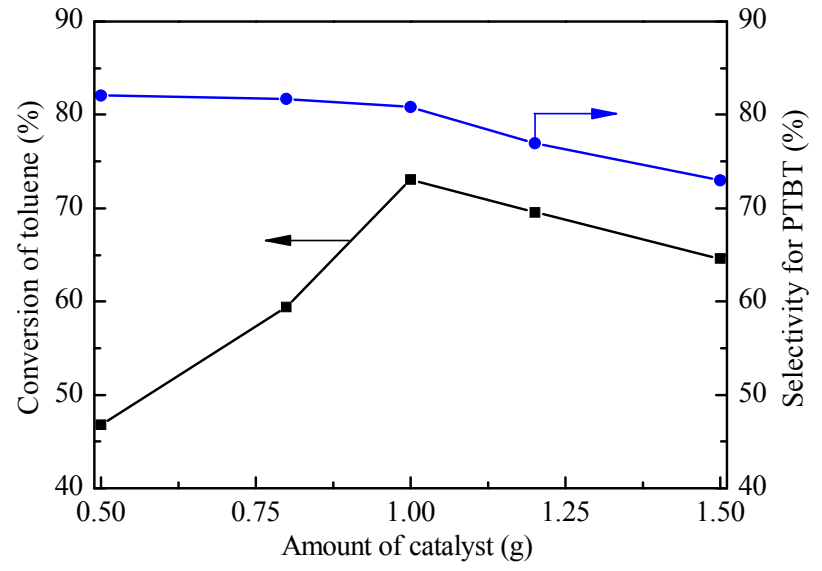

Fig. 7. Effects of catalyst amount on alkylation.

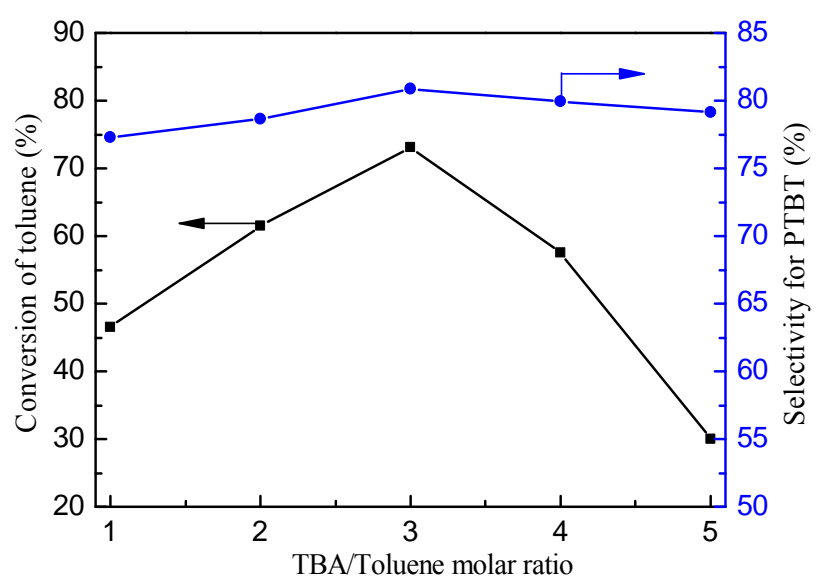

Fig. 8. Effects of TBA/toluene molar ratio on alkylation.

$\mu \mathrm{mol} / \mathrm{g}$ ). The larger number of B active sites on $\mathrm{HPW} / \mathrm{H} \beta$ increased the catalytic activity. The toluene conversion over $\mathrm{HPW} / \mathrm{H} \beta$ reached $73.1 \%$, which is much higher than that achieved over $\mathrm{H} \beta(54.0 \%)$.

Fig. 6 shows that the $\mathrm{NH}_{3}$-TPD curves of the parent $\mathrm{H} \beta$ and $\mathrm{HPW} / \mathrm{H} \beta$ contained two $\mathrm{NH}_{3}$ desorption peaks. The strong peaks in the range $150-400{ }^{\circ} \mathrm{C}$ are assigned to weak acid sites and the peaks in the range $400-600{ }^{\circ} \mathrm{C}$ are assigned to strong acid sites [29-30]. Fig. 6 clearly shows that the total amount of acid sites determined using $\mathrm{NH}_{3}$-TPD correlates well with the Py-IR results; the amounts of weak and strong acid sites in $\mathrm{HPW} / \mathrm{H} \beta$ were both higher than in the parent $\mathrm{H} \beta$.

\subsection{Optimization of reaction conditions}

\subsubsection{Effects of catalyst amount}

The effects of the catalyst amount on the toluene conversion and PTBT selectivity were investigated in the range 0.5-1.5 g, using $\mathrm{HPW} / \mathrm{H} \beta$ as the catalyst (Fig. 7). The toluene conversion initially increased and then decreased with increasing catalyst amount. This is because of the increased number of acid sites. Electrophilic aromatic substitution generally occurs via formation of a carbenium ion as the intermediate. An increase in the catalyst amount increased the number of acid sites and the 


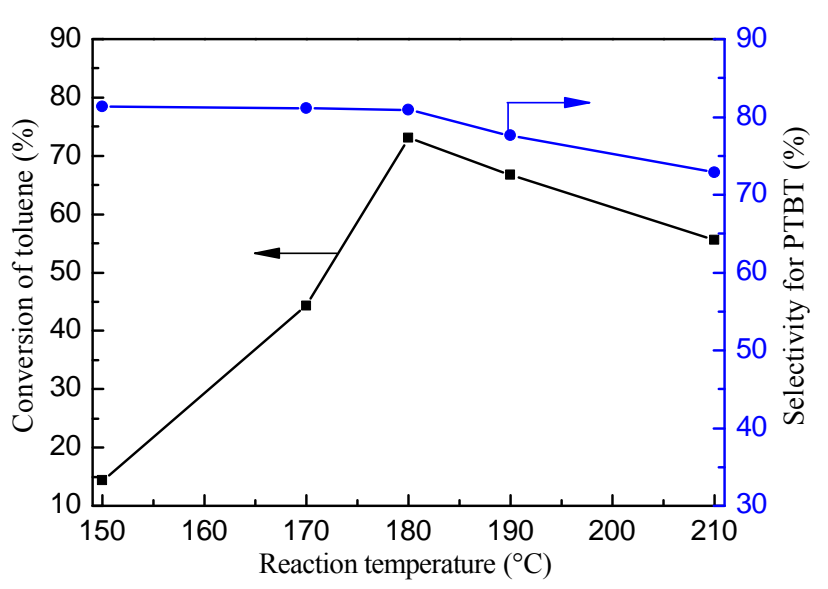

Fig. 9. Effects of reaction temperature on alkylation.

surface area, leading to the formation of more carbenium ions per unit of time, which directly increased the reaction rate. However, more acid sites on the zeolite surface accelerated the subsidiary reactions (i.e., isomerization and oligomerization), which resulted in decreases in the toluene conversion and PTBT selectivity.

\subsubsection{Effects of TBA:toluene molar ratio}

The effects of the TBA/toluene molar ratio on the toluene conversion and PTBT selectivity were studied by varying the molar ratios from $1 / 1$ to $5 / 1$ over the $\mathrm{HPW} / \mathrm{H} \beta$ catalyst at 180 ${ }^{\circ} \mathrm{C}$; the results are shown in Fig. 8. When the TBA/toluene molar ratio was increased from 1 to 3 , the toluene conversion greatly increased, from $46.5 \%$ to $73.1 \%$. When the ratio was increased to 5 , the conversion decreased to $30.0 \%$. The reason for this is that higher TBA concentrations increased oligomerization of isobutylene (formed by dehydration of TBA), and the oligomerization reaction competed with the main alkylation reaction. The best PTBT selectivity was obtained at a TBA/toluene molar ratio of $3 / 1$, showing that a small excess of TBA increased the para selectivity. Similar results were reported by Kostrab et al. [5]. They suggested that a small excess of TBA was suppressed dealkylation (cleavage of the tert-butyl group from the aromatic ring).

\subsubsection{Effects of reaction temperature}

The effects of reaction temperature on PTBT synthesis are summarized in Fig. 9. The toluene conversion clearly increased sharply when the reaction temperature was increased from

Table 3

Reusability testing of $\mathrm{HPW} / \mathrm{H} \beta$ catalyst.

\begin{tabular}{lccc}
\hline $\begin{array}{l}\text { Times of } \\
\text { repeated use }\end{array}$ & $\begin{array}{c}\text { Conversion of } \\
\text { toluene }(\%)\end{array}$ & $\begin{array}{c}\text { Selectivity to } \\
\text { PTBT }(\%)\end{array}$ & $\begin{array}{c}\text { Yield of PTBT } \\
(\%)\end{array}$ \\
\hline 0 & 73.1 & 80.8 & 59.1 \\
1 & 69.4 & 80.5 & 55.9 \\
2 & 64.3 & 81.2 & 52.2 \\
3 & 64.0 & 80.7 & 51.6 \\
4 & 59.1 & 81.3 & 48.0 \\
\hline
\end{tabular}

Reaction conditions: $\mathrm{TBA} /$ toluene molar ratio $=3 / 1$, catalyst amount $=$ $1.0 \mathrm{~g}$, reaction temperature $=180^{\circ} \mathrm{C}$, reaction time $=4 \mathrm{~h}$.
150 to $180^{\circ} \mathrm{C}$, and the toluene conversion then decreased with further temperature increases. Based on these results, we suggest that the numbers of activated toluene molecules and activated tert-butyl carbenium species increase with increasing temperature, which results in increased toluene conversion. However, the toluene conversion decreases above $180^{\circ} \mathrm{C}$. This is because the decomposition rate of PTBT increases quickly as the temperature increases. The selectivity for PTBT decreases as the temperature increases. This is because a higher temperature favors secondary reactions, which are dominant at higher reaction temperatures, therefore the toluene conversion and PTBT selectivity decrease.

\section{3. $\quad H P W / H \beta$ catalyst reusability tests}

Reusability is an important factor for an industrial catalyst. The reusability of $\mathrm{HPW} / \mathrm{H} \beta$ was tested over four cycles; the results are shown in Table 3. After four cycles, the selectivity for PTBT was unchanged. However, the toluene conversion decreased from $73.1 \%$ to $59.1 \%$, and the PTBT yield decreased from $59.1 \%$ to $48.0 \%$. Drops of $19.2 \%$ for toluene conversion and $18.8 \%$ for the PTBT yield were observed compared with those in the first cycle. HPW/H $\beta$ gave a relatively stable catalytic performance. HPW leaching into the reaction mixture and deactivation of active sites during the reaction were responsible for the decreases in the catalytic performance of $\mathrm{HPW} / \mathrm{H} \beta$.

\section{Conclusions}

A novel synthesis of PTBT via Friedel Crafts alkylation of toluene with TBA using $\mathrm{HPW} / \mathrm{H} \beta$ as the catalyst was developed. The catalytic activity and product selectivity of $\mathrm{HPW} / \mathrm{H} \beta$ were better than those of the other zeolites tested in this study. The results show that loading HPW on $\mathrm{H} \beta$ effectively increased the $B$ acidity and decreased the pore size of $\mathrm{H} \beta$. The B acidity of $\mathrm{HPW} / \mathrm{H} \beta$ was $142.97 \mu \mathrm{mol} / \mathrm{g}$, an increase of $69.74 \%$ compared with that of $\mathrm{H} \beta(84.23 \mu \mathrm{mol} / \mathrm{g})$. The catalytic activity of $\mathrm{HPW} / \mathrm{H} \beta$ was better than that of the parent $\mathrm{H} \beta$ zeolite because its high $\mathrm{B}$ acidity. The toluene conversion over HPW/H $\beta$ reached $73.1 \%$, which is much higher than that over $\mathrm{H} \beta$ (54.0\%). HPW loading on $\mathrm{H} \beta$ decreased the $\mathrm{H} \beta$ BET surface area from 492.5 to $379.6 \mathrm{~m}^{2} / \mathrm{g}$, accompanied by a significant decrease in the pore size, from 3.90 to $3.17 \mathrm{~nm}$. Shape selectivity therefore played a more important role in the product selectivity of the $\mathrm{HPW} / \mathrm{H} \beta$ catalyst than in that of the parent $\mathrm{H} \beta$. PTBT (kinetic diameter $0.58 \mathrm{~nm}$ ) can easily diffuse through the narrowed pores of HPW/H $\beta$, but the diffusion of MTBT (kinetic diameter $0.65 \mathrm{~nm}$ ) is restricted because of steric hindrance in these narrowed pores. This improved the PTBT selectivity over $\mathrm{HPW} / \mathrm{H} \beta$ (around $81.0 \%$ ). $\mathrm{HPW} / \mathrm{H} \beta$ gave a relatively stable catalytic performance in reusability tests.

\section{References}

[1] W. Y. Li, Y. H. Xu, J. Q. Wang, Z. B. Zhai, Z. Y. Yan, Y. L. Yang, Catal. Lett., 2007, 119, 327-331.

[2] W. Y. Zhou, J. G. Pan, F. A. Sun, K. Huang, M. Y. He, Q. Chen, Reac. 


\title{
Graphical Abstract
}

Chin. J. Catal., 2016, 37: 2134-2141 doi: 10.1016/S1872-2067(16)62587-1

\section{Alkylation of toluene with tert-butyl alcohol over HPW-modified H $\beta$ zeolite}

Yuanyuan Wang, Hua Song *, Xinglong Sun Northeastern Petroleum University; Daqing Petrochemical Engineering Co., Ltd.

The improved catalytic activity over $\mathrm{HPW} / \mathrm{H} \beta$ can be attributed to higher B acidity after HPW loading on $\mathrm{H} \beta$ zeolite. The improved para selectivity can be attributed to the narrower pores in $\mathrm{HPW} / \mathrm{H} \beta$.

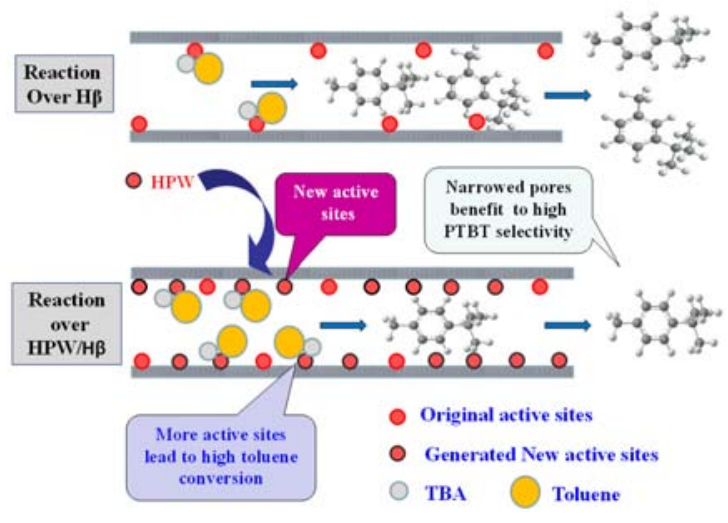

Kine. Mech. Catal., 2016, 117, 789-799.

[3] W. H. Yu, Z. R. Zhang, H. Wang, Z. H. Ge, T. J. Pinnavaia, Microporous Mesoporous Mater., 2007, 104, 151-158.

[4] S. Pai, U. Gupta, S. Chilukuri, J. Mol. Catal. A, 2007, 265, 109-116.

[5] G. Kostrab, M. Lovič, I. Janotka, M. Bajus, D. Mravec, Appl. Catal. A, 2007, 323, 210-218.

[6] L. B. Chen, H. J. Dong, L. Shi, Ind. Eng. Chem. Res., 2010, 49, 7234-7238.

[7] H. J. Dong, L. Shi, Ind. Eng. Chem. Res., 2010, 49, 2091-2095.

[8] G. Kostrab, D. Mravec, M. Bajus, I. Janotka, Y. Sugi, S. J. Cho, J. H. Kim, Appl. Catal. A, 2006, 299, 122-130.

[9] D. Mravec, P. Zavadan, A. Kaszonyi, J. Joffre, P. Moreau, Appl. Catal. A, 2004, 257, 49-55.

[10] C. P. Sebastian, S. Pai, N. Sharanappa, C. V. V. Satyanarayana, J. Mol. Catal. A, 2004, 223, 305-311.

[11] Y. Y. Wang, H. Song, H. L. Song, X. L. Sun, X. Q. Wang, Progr. React. Kinet. Mec., 2016, 41, 126-134.

[12] H. K. Min, S. H. Cha, S. B. Hong, ACS Catal., 2012, 2, 971-981.

[13] M. Selvaraj, S. H. Jeon, J. Han, P. K. Sinha, T. G. Lee, Appl. Catal. A, 2005, 286, 44-51.

[14] M. T. Portilla, F. J. Llopis, C. Martínez, S. Valencia, A. Corma, Appl. Catal. A, 2011, 393, 257-268.

[15] J. C. Zhang, B. H. Chen, C. Y. Li, Z. G. Zhu, L. Y. Wen, E. Z. Min, Appl. Catal. A, 2003, 249, 27-34.

[16] Y. Kamiya, Y. Ooka, C. Obara, R. Ohnishi, T. Fujita, Y. Kurata, K. Tsuji, T. Nakajyo, T. Okuhara, J. Mol. Catal. A, 2007, 262, 77-85.

[17] J. Wang, H. O. Zhu, Catal. Lett., 2004, 93, 209-212.
[18] X. L. Sheng, Y. M. Zhou, Y. W. Zhang, M. W. Xue, Y. Z. Duan, Chem. Eng. J., 2012, 179, 295-301.

[19] B. M. Devassy, G. V. Shanbhag, F. Lefebvre, S. B. Halligudi, J. Mol. Catal. A, 2004, 210, 125-130.

[20] K. F. Liu, S. J. Xie, S. L. Liu, G. L. Xu, N. N. Gao, L. Y. Xu, J. Catal., 2011, 283, 68-74.

[21] C. W. Hu, M. Hashimoto, T. Okuhara, M. Misono, J. Catal., 1993, 143, 437-448.

[22] N. Essayem, A. Holmqvist, P. Y. Gayraud, J. C. Vedrine, Y. B. Taarit, J. Catal., 2001, 197, 273-280.

[23] P. Ferreira, I. M. Fonseca, A. M. Ramos, J. Vital, J. E. Castanheiro, Catal. Commun., 2009, 10, 481-484.

[24] G. Y. Bai, H.H. Zhang, T. Y. Li, H. X. Dong, J. Han. Res. Chem. Intermediat.,2015, 41, 5041-5048.

[25] G. S. Kumar, M. Vishnuvarthan, M. Palanichamy, V. Murugesan, J. Mol. Catal. A, 2006, 260, 49-55.

[26] H. Song, X. W. Xu, H. L. Song, N. Jiang, F. Y. Zhang, Catal. Commun., 2015, 63, 52-55.

[27] Y. D. Wang, Z. C. Tao, B. S. Wu, J. Xu, C. F. Huo, K. Li, H. M. Chen, Y. Yang, Y. W. Li, J. Catal., 2015, 322, 1-13.

[28] W. Alabi, L. Atanda, R. Jermy, S. Al-Khattaf, Chem. Eng. J., 2012 , 195-196, 276-288.

[29] W. Q. Zhao, C. H. Yi, B. L. Yang, J. Y. Hu, X. M. Huang, Fuel Process. Technol., 2013, 112, 70-75.

[30] J. T. Li, L. L. Lou, Y. J. Yang, H. Hao, S. X. Liu, Microporous Mesoporous Mater., 2015, 207, 27-32.

\section{HPW改性H $\beta$ 分子篎催化甲苯和叔丁醇烷基化反应的性能}

\author{
王园园 ${ }^{\mathrm{a}}$, 宋 华 ${ }^{\mathrm{a}}$, 孙兴龙 ${ }^{\mathrm{b}}$ \\ a东北石油大学化学化工学院, 黑龙江大庆 163318 \\ b 大庆石化工程有限公司, 黑龙江大庆 163714
}

摘要: PTBT是一种十分重要的有机材料, 但传统制备工艺存在能耗较高, 工艺复杂, 环境污染严重等诸多问题. 为解决上述
问题, 人们提出甲苯和叔丁醇直接一步合成PTBT来代替传统的合成工艺. 甲苯和叔丁醇原料来源丰富, 用酸性分子笁等催
化剂催化甲苯和叔丁醇烷基化反应合成PTBT不但能节约成本, 简化分离和提纯工艺, 还能防止环境污染和设备腐蚀. 但催
化剂的活性低、稳定性差制约了该反应的工业化进程. 甲苯和叔丁醇侧链烷基化反应历程复杂, 需要催化剂的酸性和孔道
结构的协同作用, 因此设计催化活性高、选择性好、稳定性强的催化剂是一项十分具有挑战的研究课题. 我们采用浸渍法 
成功制备了 $\mathrm{H}_{3} \mathrm{PW}_{12} \mathrm{O}_{40}$ 改性 $\mathrm{H} \beta$ 分子篎催化剂(HPW/H $\beta$ ), 并采用XRD, SEM, TEM, ICP, FT-IR, BET, NH $\mathrm{N}_{3}-\mathrm{TPD}$ 和Py-IR等手 段对分子笁催化剂样品进行了表征, 并以甲苯和叔丁醇烷基化反应为探针反应, 研究了 HPW/H $\beta$ 分子篎催化剂的催化性能.

由SEM 分析可知, HPW/H $\beta$ 分子笁催化剂的形貌与 $\mathrm{H} \beta$ 并无明显差异, 形状规整, 粒度均匀, 晶体形貌较好, 表明 HPW 的 引入对 $\mathrm{H} \beta$ 颗粒结构无明显影响. 由XRD分析可知, 与未改性 $\mathrm{H} \beta$ 分子篎相比, HPW/H $\beta$ 样品的出峰位置和峰形基本保持一 致, 表明HPW在H $\beta$ 表面呈均匀分散状态, 但负载HPW后H $\beta$ 结晶度略有下降. 由 TEM分析可知, 负载HPW后的H $\beta$ 分子篮依 然保持规整的三维立方孔道结构, 且孔径均一, 表明负载HPW后的H $\beta$ 分子篎的骨架结构没有被破坏, 黑色阴影部分或者斑 点即为夹心型杂多酸阴离子在分子篮 $\mathrm{H} \beta$ 上的固载位. 由FT-IR 分析可知, HPW和H $\beta$ 之间存在键合作用, 部分HPW已成功分 散到 $\mathrm{H} \beta$ 骨架表面上. 由BET分析可知, 和 $\mathrm{H} \beta$ 原粉相比较, HPW/H $\beta$ 的比表面积、孔容、孔径均有所下降, BET比表面积从 492.5 下降到 $379.6 \mathrm{~m}^{2} / \mathrm{g}$, 而孔径从 3.90 下降至 $3.17 \mathrm{~nm}$. 这是因为HPW对分子篮孔道具有修饰作用, 使分子笁的孔径有所降 低. 由 $\mathrm{NH}_{3}$-TPD和Py-IR酸性表征可知, 负载HPW能有效增加H $\beta$ 沸石分子笁的酸量, 尤其是B酸量. 未改性H $\beta$ 的B酸含量为 $84.23 \mu \mathrm{mol} / \mathrm{g}$, 而 $\mathrm{HPW} / \mathrm{H} \beta$ 的B酸含量为 $142.97 \mu \mathrm{mol} / \mathrm{g}$, 增加了 $69.74 \%$.

由酸性表征可知, $\mathrm{H} \beta$ 的总酸量小, B酸含量低, 因而催化活性弱, 甲苯转化率仅为 $54.0 \%$. 另外, H $\beta$ 分子篎的 12 元环直通 道的孔道开口尺寸为 $0.66 \mathrm{~nm} \times 0.67 \mathrm{~nm}$, PTBT (动力学直径 $0.58 \mathrm{~nm}$ ) 和MTBT (动力学直径 $0.65 \mathrm{~nm}$ ) 都能够从其孔道中扩散 出来, 因而分子笁孔道的择形作用对产物的选择性作用较小, PTBT的选择性 $(69.6 \%)$ 较低. 负载HPW能有效增加H $\beta$ 分子篎 的总酸量, 尤其是B酸量, 而B酸量增加, 有利于反应中正碳离子生成, 因而增加催化活性. 另外, HPW改性还能提高PTBT 的选择性, 这是因为HPW对分子篎孔道具有修饰作用, 使分子篎的孔径有所降低. 而适量减小的孔径使得分子篎的择形作 用大大增加, 体积较小的PTBT能从孔道中扩散出来, 而体积较大的MTBT, 由于空间位阻的作用, 很难从其中扩散出来, 从 而增加了对位选择性. 通过对 HPW/H $\beta$ 催化甲苯和叔丁醇烷基化反应工艺条件进行考察, 确定了适宜的反应条件: 环己烷 $60 \mathrm{~mL}$, 催化剂 $1.0 \mathrm{~g}, n$ (叔丁醇) $/ n$ (甲苯) $=3 / 1$, 反应温度 $180{ }^{\circ} \mathrm{C}$, 反应时间 $4 \mathrm{~h}$. 此条件下甲苯转化率为 $73.1 \%, \mathrm{PTBT}$ 的选择性 为 $80.8 \%$.

关键词: 烷基化; 甲苯; 叔丁醇; $\mathrm{H}_{3} \mathrm{PW}_{12} \mathrm{O}_{40} ; \mathrm{B}$ 酸性; $\mathrm{H} \beta$ 分子篮

收稿日期: 2016-09-29. 接受日期: 2016-10-27. 出版日期: 2016-12-05.

*通讯联系人. 电话: (0459)6503167; 传真: (0459)6506498; 电子信箱：songhua2004@sina.com

本文的英文电子版由Elsevier出版社在ScienceDirect上出版(http://www.sciencedirect.com/science/journal/18722067). 